\title{
Justiça multiportas: mediação, conciliação e arbitragem no Brasil'
}

\author{
Multi-door court house system: mediation, conciliation and arbitration in Brazil
}

Leonardo Carneiro da Cunha'

'Universidade Federal de Pernambuco - Brasil

\section{Resumo}

O presente texto trata dos meios adequados de solução de disputas no Brasil, apresentando um panorama das principais normas sobre mediação, conciliação e arbitragem no seu sistema.

Palavras-chave: Meios Adequados de Solução de Disputas. Mediação. Conciliação. Arbitragem.

\begin{abstract}
This text deals with the ADRs in Brazil, presenting an overview of the mains rules on mediation, conciliation and arbitration in your system.
\end{abstract} Keywords: ADRs. Mediation. Conciliation. Arbitration.

\section{Introdução}

\subsection{0 modelo do sistema multiportas de solução de disputas}

Quando duas ou mais pessoas disputam o mesmo bem ou direito, podem resolver seu conflito por um dos seguintes métodos: (a) conciliando interesses; (b) submetendo a disputa a um terceiro que determinará quem tem razão; (c) adotando alguma medida que determinará quem tem mais poder².

A conciliação de interesses é método próprio dos meios de autocomposição. Determinar quem tem razão é o método da heterocomposição, seja pela arbitragem, seja pela justiça estatal. E determinar quem tem mais poder é o método de uma votação, de uma guerra ou de uma greve.

Todos esses métodos sujeitam-se a riscos, a custos, a satisfação com o resultado, a efeitos que produzem na relação havida entre as partes e a recorrência conflitual.

Costumam-se chamar de "meios alternativos de resolução de conflitos" a mediação, a conciliação e a arbitragem (Alternative Dispute Resolution - ADR). Estudos mais recentes demonstram que tais meios não

1 O texto corresponde, com posteriores acréscimos, à palestra proferida no Colóquio Lusófono de Direito Processual Civil, realizado nos dias 7 e 8 de novembro de 2019, na Praia, Cabo Verde, no Instituto Superior de Ciências Jurídicas e Sociais - ISCJS, em parceria com o Conselho Superior de Magistratura Judicial de Cabo Verde - CSMJ e com a Associação Norte e Nordeste de Professores de Processo - ANNEP.

2 URY, William; BRETT, Jeanne; GOLDBERG, Stephen. Resolução de conflitos. Trad. Soares Franco. Lisboa: Actual Editora, 2009, p. 36 . 
seriam "alternativos", mas sim adequados, formando um modelo de sistema de justiça multiportas. Para cada tipo de controvérsia, seria adequada uma forma de solução, de modo que há casos em que a melhor solução há de ser obtida pela mediação, enquanto outros, pela conciliação, outros, pela arbitragem e, os que se resolveriam pela decisão do juiz estatal. Há, ainda, outros meios, a exemplo da negociação direta ${ }^{3}$ e do dispute board.

Tais meios sempre foram examinados a partir do lugar de sua aplicação: toda a análise sempre levou em conta sua realização em ambiente judicial ou não. Sua adoção, ainda no início do século XX, era gerida pelo Poder Judiciário; havia um protagonismo do Judiciário na gestão e na condução da mediação, da conciliação e da arbitragem ${ }^{4}$. O juiz, muitas vezes, conduzia, ele mesmo, a sessão de mediação ou de conciliação ou encaminhava as partes à arbitragem.

O lugar de aplicação desses meios vem deixando de ocupar a centralidade de sua análise. Daí a tendência de designá-los como meios de resolução adequada de disputas - RAD, ao lado da própria opção pelo Judiciário, adequado para inúmeros $\operatorname{casos}^{5}$.

Ao longo do tempo, a escolha entre os vários meios alternativos de solução de controvérsias deu-se por diversos motivos, alguns deles utilitaristas, como a economia de tempo, simplificação, redução de custos. ${ }^{6}$

Na realidade, a adoção dos $A D R$ 's não tem por finalidade reduzir a litigiosidade ou dar uma resposta racional ao forte crescimento de demandas judiciais; num primeiro momento, surgiu com essa finalidade, fortalecendo-se depois como uma resposta ao hiperlegalismo e, mais recentemente, como meios adequados a solução de determinadas disputas .

Os meios de solução de disputas são, portanto, adequados, mas também são integrados. É possível que o meio mais adequado seja a mediação, mas, não obtida a autocomposição, a opção passa a ser a arbitragem ou a jurisdição estatal. Para cada situação, há um meio adequado, mas ele é integrado com outro(s), que também revela(m) adequação para o caso.

Há casos, então, em que o meio alternativo é que seria o da justiça estatal. A expressão multiportas decorre de uma metáfora: seria como se houvesse, no átrio do fórum, várias portas; a depender do problema apresentado, as partes seriam encaminhadas para a porta da mediação, ou da conciliação, ou da arbitragem, ou da própria justiça estatal.

O meio de solução há de ser o mais adequado. A adequação é o fundamento para que se adote o meio mais eficiente para a resolução de disputas. Não se deve adotar apenas a mediação, a conciliação, a arbitragem ou a justiça estatal. Há muitos outros meios de solução, que podem ser imaginados, construídos ou combinados entre si. É preciso que o profissional do direito seja um designer e construa concretamente a melhor forma, a mais adequada, a mais eficiente para solucionar a controvérsia instalada entre as partes $^{8}$. É exatamente por isso que os procedimentos judiciais devem ser flexíveis, a fim de se ajustarem às peculiaridades do caso, com mais eficiência e efetividade ${ }^{9}$.

O direito brasileiro, a partir da Resolução 125, de 2010, do Conselho Nacional de Justiça e com o Código de Processo Civil de 2015, construiu um sistema de justiça multiportas, com cada caso sendo indicado para o método ou técnica mais adequada para a solução do conflito. O Judiciário deixa de ser um lugar

3 Sobre a negociação direta como meio de solução de disputas, consultar: CUNHA, Leonardo Carneiro da; CABRAL, Antonio do Passo. Negociação direta ou resolução colaborativa de disputas (collaborative law): "mediação sem mediador". Revista de Processo, São Paulo: RT, v. 259, p. 471-489, set. 2016.

4 CHASE, Oscar G. Derecho, cultura y ritual: sistemas de resolución de controversias en un contexto intercultural. Madrid: Marcial Pons, 2011, p. 136-139.

5 VASCONCELOS, Carlos Eduardo. Mediação de conflitos e práticas restaurativas. 3a ed. São Paulo: Método, 2014 , p. 53.

6 ENGEL, Martin. Collaborative law: mediation ohne mediator. Tübingen: Mohr Siebeck, 2010, p. 42 ss.

7 CHASE, Oscar G. Ob. cit., p. 143-155.

8 FALECK, Diego. Manual de design de sistema de disputas: criação de estratégias e processos eficazes para tratar conflitos. Rio de Janeiro: Lumen Juris, 2018.

9 DIDIER JR., Fredie; CABRAL, Antonio do Passo; CUNHA, Leonardo Carneiro da. Por uma nova teoria dos procedimentos especiais: dos procedimentos às técnicas. Salvador: JusPodivm, 2018. 
de julgamento apenas para ser um local de resolução de disputas. Trata-se de uma importante mudança paradigmática. Não basta que o caso seja julgado; é preciso que seja conferida uma solução adequada que faça com que as partes saiam satisfeitas com o resultado. ${ }^{10}$

A partir da exigência de uma Administração Pública eficiente (CF, art. 37), que desenvolva um adequado modelo de gestão e incorpore técnicas da administração gerencial, e diante do incremento das ideias democráticas, a atividade administrativa passou a exigir maior participação social institucionalizada; o particular passa a poder participar da construção das decisões administrativas, sendo compartícipe da gestão pública ${ }^{11}$. Há, enfim, uma atuação administrativa consensual. ${ }^{12}$

A consensualidade, presente no processo decisório, na fase executiva e no momento de solução de conflitos, caracteriza a Administração Pública dialógica, que é a Administração Pública inserida no regime democrático, num estágio ainda mais avançado que o da Administração Pública gerencial. ${ }^{13}$

É possível perceber uma ampliação gradativa, ao longo dos anos, de manifestações de consensualidade administrativa no Direito brasileiro. De igual modo, o ambiente da consensualidade tem sido incrementado no Direito Penal, no Direito Processual e, em geral, no Direito Público. Com efeito, existem a desapropriação amigável, a colaboração premiada, a transação penal e a suspensão condicional do processo, a autocomposição nos processos que tramitam nos Juizados Especiais Federais e nos Juizados Especiais da Fazenda Pública, os acordos de leniência, além do próprio incremento das Parcerias PúblicoPrivadas. ${ }^{14}$ A legislação que trata das agências reguladoras outorga-lhes poder para dirimir, no âmbito administrativo, as divergências entre concessionárias, permissionárias, autorizatárias etc. ${ }^{15}$

É nesse ambiente de maior consensualidade que a arbitragem tem se expandido para solução de disputas envolvendo entes da Administração Pública, aumentando os casos em que se viabiliza a autocomposição, por meio da mediação e da conciliação, de que participe o Poder Público.

Com efeito, o ambiente de consensualidade da Administração Pública dialógica contribui para a celebração de transações administrativas, conciliações e mediações e, até mesmo, para a realização de arbitragens envolvendo o Poder Público. ${ }^{16}$ A arbitragem não é meio consensual de solução de disputas; é um mecanismo heterocompositivo, e não autocompositivo. Sua instauração, porém, exige consenso: as partes envolvidas precisam aceitar que o caso não vá ao Judiciário, podendo ser submetido a um tribunal arbitral.

Nos termos do art. 26 da Lei de Introdução às Normas do Direito Brasileiro, a autoridade administrativa, para eliminar irregularidades, incerteza jurídica ou situações contenciosas na aplicação do direito público, inclusive no caso de expedição de licença, pode celebrar compromisso com os interessados. O compromisso buscará solução jurídica proporcional, equânime, eficiente e compatível com os interesses gerais, não poderá conferir desoneração permanente de dever ou condicionamento de direito reconhecidos por orientação geral e deverá prever, com clareza, as obrigações das partes, o prazo para seu cumprimento e as sanções aplicáveis em caso de descumprimento.

Tal dispositivo, como bem destaca Edilson Pereira Nobre Júnior, contém disposição de caráter geral que se destina a conferir dosagem democrática ao Direito Administrativo brasileiro, ao permitir que

10 Sobre essa mudança e os diversos desafios para sua implementação, consultar, LESSA NETO, João Luiz. O novo CPC adotou o modelo multiportas!!! E agora?!. Revista de Processo. São Paulo: RT, v. 244, jun. 2015, p. $427-441$.

11 "Fenômeno relativamente recente nas relações entre o Estado e os indivíduos na realização de fins de interesse público tem sido a busca de decisões administrativas por meios consensuais" (SILVA, Almiro do Couto e. Os indivíduos e o Estado na realização de tarefas públicas. Conceitos fundamentais do direito no Estado Constitucional. São Paulo: Malheiros, 2015, p. 261).

12 BARREIROS, Lorena Miranda Santos. Convenções processuais e Poder Público. Salvador: JusPodivm, 2016. n. 1.3, p. 4549. FACCI, Lucio Picanço. Meios adequados de resolução de conflitos administrativos: a experiência da Câmara de Conciliação e Arbitragem da Administração Federal. Rio de Janeiro: Lumen Juris, 2019, n. 2.3.1, p. 128-132.

13 Para mais detalhes, consultar LIMA, Raimundo Márcio Ribeiro. Administração Pública dialógica. Curitiba: Juruá, 2013.

14 BARREIROS, Lorena Miranda Santos. Ob. cit., n. 1.4, p. 49-92.

15 FACCI, Lucio Picanço. Ob. cit., n. 2.3.2, p. 133.

16 LIMA, Raimundo Márcio Ribeiro. Administração Pública dialógica. Curitiba: Juruá, 2013, n. 4.5, p. 233. 
a Administração - de qualquer de suas esferas políticas - incorpore o consenso na tomada de suas decisões. A disposição satisfaz, a um só tempo, exigências de legalidade e de eficiência, autorizando o agente público a agir pela pauta consensual, fazendo com que o acordado seja suscetível de mais fácil cumprimento, com o que se evita o recurso, penoso e demorado, à via judicial. Há, enfim, a incorporação da tendência à implantação da administração concertada, ou administração consensual, ou ainda soft administration, que expressam novas formas de democracia participativa ${ }^{17}$.

No âmbito federal, tal previsão foi regulamentada pelo Decreto 9.830, de 2019, contendo, em seus arts. 10 e 11, detalhamento sobre a celebração de compromisso, bem como de termo de ajustamento de gestão.

Tal disposição contida no art. 26 da Lei de Introdução contém, a bem da verdade, uma cláusula geral estimuladora da adoção de meios consensuais pelo Poder Público ${ }^{18}$. Aliás, por força do art. 30 da mesma LINDB, o Poder Público deve desenvolver procedimentos internos hábeis a identificar casos para sugerir a aplicação dos meios consensuais de conflito ${ }^{19}$.

Esses dispositivos - aliados aos arts. $3^{\circ}$ e 174 do CPC - estabelecem o dever de a Administração Pública adotar meios consensuais de solução de disputas.

O sistema multiportas de solução de disputas é, enfim, compatível com o ambiente público, podendo abranger as controvérsias que envolvam a Fazenda Pública, bem como aquelas travadas entre particulares. Não há restrições de temas ou de sujeitos de direito envolvidos na disputa. O sistema multiportas é abrangente, alcançando uma ampla variedade de hipóteses conflituosas.

\section{A arbitragem no Brasil}

\subsection{A legislação brasileira}

A Lei 9.307, de 1996, dispõe sobre a arbitragem e estabelece, logo no seu art. $1^{\circ}$, que "as pessoas capazes de contratar poderão valer-se da arbitragem para dirimir litígios relativos a direitos patrimoniais disponíveis”. É preciso, então, que haja a presença de requisitos subjetivos (capacidade jurídica) e objetivos (direito patrimonial disponível).

As partes interessadas podem submeter a solução de seus litígios ao juízo arbitral mediante convenção de arbitragem, assim entendida a cláusula compromissória e o compromisso arbitral. Em outras palavras, a convenção de arbitragem é o gênero, do qual há duas espécies: a cláusula compromissória e o compromisso arbitral.

A cláusula compromissória é, nos termos do art. $4^{\text {o }}$ da Lei 9.307, de 1996, "a convenção através da qual as partes em um contrato comprometem-se a submeter à arbitragem os litígios que possam vir a surgir, relativamente a tal contrato". A cláusula compromissória deve ser estipulada por escrito, podendo inserir-se no próprio contrato ou em documento apartado que a ele se refira. Já o compromisso arbitral, segundo disposto no art. 9º da mesma lei, "é a convenção através da qual as partes submetem um litígio à arbitragem de uma ou mais pessoas, podendo ser judicial ou extrajudicial”. Enquanto o compromisso extrajudicial deve ser celebrado por instrumento público ou por escrito particular, assinado por duas testemunhas, o judicial há de ser celebrado por termo nos autos, perante o juízo ou tribunal, onde tenha curso a demanda. Tanto a cláusula compromissória quanto o compromisso arbitral produzem o chamado efeito vinculante, submetendo efetivamente as partes à arbitragem.

A autoridade legislativa, em tais dispositivos, fornece "interpretação" ao texto normativo. Há aí, então, uma norma interpretativa. Não é incomum que a autoridade normativa assuma a tarefa de fixar

17 NOBRE JÚNIOR, Edilson Pereira. As normas de direito público na Lei de Introdução ao Direito Brasileiro: paradigmas para interpretação e aplicação do Direito Administrativo. São Paulo: Contracorrente, 2019, p. 144-145.

18 Nesse sentido, o enunciado 130 do Fórum Nacional do Poder Público: "O art. 26 da LINDB prevê cláusula geral estimuladora da adoção de meios consensuais pelo Poder Público e, para sua aplicação efetiva e objetiva, recomenda-se a produção de repositório público de jurisprudência administrativa”.

19 Nesse sentido, o enunciado 131 do Fórum Nacional do Poder Público: "Deve o Poder Público desenvolver procedimentos internos hábeis a identificar casos para sugerir a aplicação dos meios consensuais de conflito". 
o significado do texto normativo, fazendo-o de duas maneiras: ou editando "leis interpretativas", ou editando "definições legislativas". Aqui o legislador editou uma definição legislativa, já antecipando o significado que se deve atribuir à cláusula compromissória e ao compromisso arbitral. Busca-se, com isso, eliminar discussões a respeito da identificação de cada uma dessas convenções de arbitragem.

Pela cláusula compromissória, as partes comprometem-se a submeter a controvérsia a um juízo arbitral. Por sua vez, o compromisso arbitral é a convenção pela qual as partes já submetem a controvérsia a um juízo arbitral.

O Código Civil, ao tratar das várias espécies de contrato, disciplina o compromisso em seus arts. 851, 852 e 853. Nos termos do Código Civil, é admitido o compromisso, judicial ou extrajudicial, para resolver litígios entre pessoas que podem contratar, sendo certa, ademais, a admissibilidade de inclusão nos contratos da cláusula compromissória, a fim de resolver divergências mediante juízo arbitral, na forma estabelecida em lei especial. O art. 852 veda expressamente o compromisso arbitral para solução de questões de estado, de direito pessoal de família e de outras que não tenham caráter estritamente patrimonial.

É possível haver cláusula compromissória em contrato de adesão. Não há vedação nesse sentido. A Lei 9.307, de 1996, apenas contém algumas exigências, a fim de resguardar a situação do aderente. Para que a cláusula compromissória seja eficaz nos contratos de adesão, é preciso que o aderente tome a iniciativa de instituir a arbitragem ou concordar, expressamente, com a sua instituição, desde que o faça por escrito em documento anexo ou em negrito, com a assinatura ou visto especialmente para essa cláusula. Não importa se o negócio é de consumo. Sendo o contrato de adesão, há de ser respeitar tais exigências, sob pena de completa ineficácia da cláusula compromissória, a ser considerada como não escrita.

A arbitragem pode ser de direito ou de equidade, a critério das partes, que poderão, ainda, escolher as regras de direito que serão aplicadas, ou convencionar que o julgamento se realize com base nos princípios gerais do direito, nos usos e costumes e nas regras internacionais de comércio.

As partes podem, na cláusula compromissória, já estabelecer as regras necessárias e suficientes para a instituição da arbitragem, ou simplesmente reportar-se às regras de algum órgão arbitral institucional ou entidade especializada, de maneira que, sobrevindo a controvérsia, é possível a instituição imediata da arbitragem. É o que se chama de cláusula compromissória cheia.

No caso de a cláusula compromissória ser vazia, isto é, caso não haja acordo prévio sobre a forma de instituir a arbitragem, a parte interessada manifestará à outra parte sua intenção de dar início à arbitragem, por via postal ou por outro meio idôneo de comunicação, convocando-a para firmar o compromisso arbitral. Não comparecendo a parte convocada ou, comparecendo, recusar-se a firmar o compromisso arbitral, faculta-se à outra parte a propositura de demanda judicial perante o Poder Judiciário para que o juiz estatal determine a sua celebração. Ao juiz cabe estimular uma celebração consensual. Não sendo possível e não havendo consenso, o juiz decidirá sobre o conteúdo do compromisso arbitral. $\mathrm{O}$ árbitro deve ser escolhido nos termos do compromisso arbitral. Se este nada dispuser a respeito, caberá ao juiz nomear árbitro único para a solução do litígio. A sentença do juiz valerá como compromisso arbitral, podendo ser impugnada por recurso de apelação sem efeito suspensivo, de modo que é possível já instituir a arbitragem, mesmo pendente apelação contra a sentença que determina sua instituição.

Há aí uma ação materialmente sumária, com procedimento especial. A sentença arbitral substitui a declaração de vontade da parte e vale como compromisso arbitral.

O árbitro não precisa ser bacharel em Direito, nem ter qualquer especialidade imposta pela lei. Pode ser árbitro qualquer pessoa capaz e que tenha a confiança das partes. É preciso que seja alguém imparcial; não deve ser impedido, nem suspeito. Os casos de impedimento e suspeição, previstos para os juízes, aplicam-se igualmente aos árbitros.

As partes nomearão um ou mais árbitros, sempre em número ímpar, podendo também nomear os respectivos suplentes. Quando as partes nomearem árbitros em número par, estes estão autorizados a, desde logo, nomear mais um. Não havendo acordo, as partes devem requerer ao Poder Judiciário a nomeação do árbitro. Sendo nomeados vários árbitros, estes, por maioria, elegerão o presidente do 
tribunal arbitral. Não havendo consenso, o mais idoso será designado presidente. Todas essas regras têm caráter supletivo. É sempre possível que as partes ou o regulamento da instituição que administre o processo estabeleçam regras distintas.

Ao árbitro cabe decidir, de ofício ou a requerimento das partes, as questões relativas à existência, à validade e à eficácia da convenção de arbitragem e do contrato que contenha a cláusula compromissória. O árbitro ou o tribunal arbitral poderá tomar o depoimento das partes, ouvir testemunhas e determinar a realização de perícias ou outras provas que sejam necessárias, mediante requerimento das partes ou de ofício. Em caso de recusa da testemunha para comparecer à audiência, o árbitro ou o presidente do tribunal arbitral poderá requerer ao Poder Judiciário que determine sua condução. Havendo necessidade de medidas coercitivas ou cautelares, os árbitros poderão solicitá-las ao órgão do Poder Judiciário que seria, originariamente, competente para julgar a causa.

A sentença arbitral deve conter relatório, fundamentação (mencionando-se, expressamente, se os árbitros julgaram por equidade), o dispositivo, a data e o lugar em que foi proferida.

A sentença arbitral não precisa ser homologada. Nada tendo sido convencionado, o prazo para prolação da sentença é de 6 (seis) meses, contado da instituição da arbitragem ou da substituição do árbitro. Tal prazo pode ser prorrogado de comum acordo entre as partes e o árbitro. Os árbitros podem proferir sentenças parciais, acolhendo uma parte do pedido e deixando a outra para depois, por ser necessária uma instrução mais demorada.

A sentença é irrecorrível e produz coisa julgada, constituindo título executivo judicial. O árbitro não tem poderes para processar o cumprimento da sentença, que deve ser promovido pela parte vitoriosa perante o Poder Judiciário.

Embora seja irrecorrível a sentença arbitral, a parte interessada, mediante comunicação à outra parte, pode solicitar ao árbitro ou ao tribunal arbitral que corrija erro material da sentença arbitral ou que esclareça alguma obscuridade, elimine contradição da sentença arbitral, ou se pronuncie sobre ponto omitido a respeito do qual devia manifestar-se a decisão.

O Poder Judiciário não pode rever o mérito da sentença arbitral. É possível, entretanto, que a parte interessada postule ao órgão do Poder Judiciário, mediante demanda específica, a decretação da nulidade da sentença arbitral, nas hipóteses previstas na própria lei de arbitragem. Tal demanda anulatória da sentença arbitral submete-se ao procedimento comum, previsto no CPC, devendo ser proposta no prazo de até 90 (noventa) dias após o recebimento da notificação da sentença arbitral ou de seu aditamento.

A lei da arbitragem estabelece, ainda, que a sentença arbitral estrangeira será reconhecida ou executada no Brasil de conformidade com os tratados internacionais com eficácia no ordenamento interno e, na sua ausência, estritamente de acordo com os termos da legislação nacional. Considera-se sentença arbitral estrangeira a que tenha sido proferida fora do território nacional. O Brasil adota um critério territorialista e equipara o local da prolação da sentença arbitral à sede jurídica da arbitragem. É estrangeira a sentença arbitral proferida por juízo arbitral com sede em outro país.

O Brasil aderiu tardiamente à Convenção de Nova Iorque sobre o Reconhecimento e Execução de Sentenças Arbitrais Estrangeiras de 1958, principal instrumento regulador da arbitragem no âmbito internacional e ratificado por mais de 145 países. Todas as regras constantes da convenção são aplicáveis no Brasil. Junto com a Lei de Arbitragem, a Convenção de Nova Iorque representa o principal instrumento legislativo para a arbitragem no Brasil.

Além disso, o Brasil é signatário da Convenção Interamericana sobre Arbitragem Comercial Internacional (Convenção do Panamá de 1975), que estabelece regras sobre o funcionamento do processo arbitral, capacidade para ser árbitro e reconhecimento e execução de sentenças arbitrais estrangeiras.

Seguindo a previsão constitucional, a lei da arbitragem prevê que a sentença arbitral estrangeira, para ser reconhecida ou executada no Brasil, deve ser homologada pelo Superior Tribunal de Justiça. A sentença arbitral estrangeira, homologada pelo Superior Tribunal de Justiça, é título executivo judicial e deve ser executada perante um juízo federal de primeira instância (CF, art. 109, X). A sentença arbitral estrangeira só passa a ser tida como título executivo, se for homologada pelo Superior Tribunal 
de Justiça (CF, art. 105, I, i). Enquanto não homologada, não produz efeitos no território brasileiro, não podendo ser considerada título executivo, nem servir como base para a instauração de uma execução.

É oportuno lembrar uma modificação introduzida pelo Protocolo de Cooperação e Assistência Jurisdicional em Matéria Civil, Comercial, Trabalhista e Administrativa, que o Brasil subscreveu, no âmbito do MERCOSUL, em 27 de junho de 1992. Tal convenção internacional, denominada Protocolo de Las Leñas, foi incorporada formalmente ao sistema brasileiro, pois foi aprovada pelo Congresso Nacional por meio do Decreto Legislativo 55/1995, sendo posteriormente promulgada pelo Presidente da República mediante o Decreto 2.067/1996. Em razão do Protocolo de Las Leñas - aplicável apenas às relações entre os Estados integrantes do MERCOSUL -, tornou-se possível, mediante simples carta rogatória, realizar-se a homologação e a execução, no Brasil, de sentenças estrangeiras proferidas por países integrantes do MERCOSUL.

O Protocolo de Las Leñas não autorizou a eficácia extraterritorial das sentenças estrangeiras proferidas no âmbito do MERCOSUL. Em outras palavras, não dispensou a homologação da sentença estrangeira. Apenas facilitou e simplificou o procedimento para a homologação da sentença estrangeira proveniente do MERCOSUL. ${ }^{20}$ As sentenças estrangeiras proferidas por países integrantes do MERCOSUL são homologadas pelo STJ mediante simples carta rogatória. Ao STJ cabe examinar os requisitos formais da rogatória para, então, conceder o exequatur e determinar sua remessa à Justiça Federal competente para execução da sentença.

As sentenças estrangeiras, inclusive as arbitrais, devem, portanto, ser homologadas pelo STJ para que sejam títulos executivos judiciais. Não estão dispensadas da homologação as sentenças estrangeiras dos países integrantes do MERCOSUL. Sua homologação apenas está submetida a procedimento mais simples, efetivando-se por mera carta rogatória.

\subsection{Arbitrabilidade objetiva e subjetiva}

Já se viu que a Lei 9.307, de 1996, estabelece ser possível a arbitragem para (a) as pessoas capazes de contratar, relativamente a (b) direitos patrimoniais disponíveis. São, então, dois os requisitos para que se admita uma arbitragem: a capacidade de fato ou de exercício e a disponibilidade de um direito patrimonial.

A doutrina brasileira passou a entender que a arbitragem, na verdade, depende da presença da chamada arbitrabilidade, que pode ser objetiva e subjetiva. Essas definições são mais adequadas a identificar quem pode submeter-se à arbitragem e qual a controvérsia possível a ser submetida a uma arbitragem.

A arbitrabilidade subjetiva refere-se a quem pode ser parte numa arbitragem. A legislação vale-se da expressão "pessoas capazes”. Rigorosamente, tal expressão não abrange os entes despersonalizados, a exemplo do condomínio, do espólio e das sociedades de fato. Tais entes, embora não tenham personalidade jurídica, desfrutam de capacidade. Não são poucos os doutrinadores que consideram a capacidade como a nota definidora do conceito jurídico de pessoa. Com efeito, para muitos, o direito, ao se referir a "pessoa", não utiliza o sentido ético da palavra, identificando-a com a capacidade jurídica. Por isso, a quem se confere personalidade, outorga-se igualmente capacidade. Em out ras palavras, quem tem personalidade tem, somente por isso, capacidade jurídica. Daí por que o Código Civil brasileiro, em seu art. 1.o, dispõe que toda pessoa é capaz de direitos e deveres na ordem civil.

A personalidade não se confunde, todavia, com a capacidade. Conquanto se afirme que a capacidade seja um elemento da personalidade, nem sempre que haja capacidade deve existir, necessariamente, personalidade. Em algumas hipóteses, o legislador entende desnecessário atribuir personalidade a alguns entes, mas lhes assegura capacidade jurídica e processual. Assim, por exemplo, o condomínio, a massa falida, o espólio e outros tantos, embora não desfrutem de personalidade jurídica, têm capacidade para adquirir direitos e contrair obrigações, podendo, até mesmo, ser parte em juízo, ativa ou passivamente. Tais entes não são pessoas, mas são sujeitos de direito, podendo ser titulares de poderes, deveres, direitos, ônus e faculdades, de índole material ou processual. 
Daí se infere que há sujeitos de direito que não são pessoas. Tais sujeitos não são pessoas, mas se lhes atribui capacidade jurídica, porque: (a) sua existência se caracteriza pela transitoriedade e pela fugacidade, não se recomendando seja-lhes deferida personalidade jurídica, que exige duração temporal com certa estabilidade; e, ainda, pela (b) necessidade de se conferir segurança às relações jurídicas, garantindo o exercício de pretensões de terceiros contra tais sujeitos desprovidos de personalidade jurídica. ${ }^{21}$

Se tais entes têm capacidade jurídica, podem adquirir direitos e contrair obrigações e, ainda, podem ser parte em processo judicial, não há razão para vetar-lhes o acesso à arbitragem. Há, então, arbitrabilidade subjetiva, não transparecendo qualquer impediente à celebração da arbitragem.

Além da capacidade da parte, é preciso, para que haja arbitragem, que ela possa dispor ou transigir sobre o direito patrimonial. É preciso, enfim, que haja arbitrabilidade objetiva. Exige-se, em outras palavras, que as partes tenham capacidade de administração de bens, e não de disposição. Se não há capacidade de administração de bens, não há poderes para celebração de uma convenção de arbitragem. É o caso do inventariante, do administrador judicial na falência e do síndico de um condomínio. Para celebração de uma convenção de arbitragem, essas partes necessitam das respectivas autorizações exigidas por lei para dispor de direitos (autorização judicial, no caso do inventariante e do administrador judicial, e da assembleia de condôminos, no caso do condomínio).

\subsection{Poder do árbitro para conceder medidas cautelares e de urgência}

É possível que surja uma urgência antes mesmo da instituição da arbitragem. Nesse caso, admite-se a chamada cautelar pré-arbitral: o pedido de providência de urgência deve ser formulado ao Poder Judiciário (Lei 9.307/1996, art. 22-A).

A cautelar, nesse caso, é antecedente. Intentada a cautelar antecedente e uma vez deferida, pelo juízo estatal, a providência postulada, deve ser instaurada a arbitragem dentro de 30 (trinta) dias, a contar da efetivação da medida (Lei 9.307/1996, art. 22-A, parágrafo único). Se a arbitragem não for instaurada nesse prazo, a cautelar perde sua eficácia. A medida cautelar conserva sua eficácia nesse prazo de 30 (trinta) dias e, instituída a arbitragem, pode ser mantida, revogada ou modificada pelo árbitro (Lei 9.307/1996, art. 22-B).

Instaurada a arbitragem, os autos da cautelar pré-arbitral devem ser encaminhados pelo juiz estatal ao árbitro ou ao tribunal arbitral, que passa a conduzir o caso, processando a demanda e julgando ao final os pedidos formulados.

Cabe ao juízo arbitral conceder as medidas de urgência. A análise tanto do mérito como das medidas de urgência cabe ao juízo arbitral. ${ }^{22}$

Como destaca Cândido Rangel Dinamarco, "Instaurado o processo arbitral, com a competência para processar e julgar a causa recebem os árbitros também o encargo de prover sobre eventuais pedidos incidentais de medidas urgentes". ${ }^{23}$

21 MELLO, Marcos Bernardes de. Teoria do fato jurídico: plano da eficácia - 1ª parte. São Paulo: Saraiva, 2003 , p. 127. Essa situação de transitoriedade que desaconselha a atribuição de personalidade jurídica a alguns sujeitos de direito não guarda pertinência com o condomínio edilício, que desfruta de duração temporal com certa estabilidade. Deveria, então, ser conferida personalidade jurídica ao condomínio edilício. O condomínio não tem, contudo, personalidade, mas é sujeito de direito, dotado de capacidade jurídica (MELLO, Marcos Bernardes de. Teoria do fato jurídico: plano da eficácia - 1ª parte. São Paulo: Saraiva, 2003, idem, nota de rodapé n. 235, p. 128).

22 CARMONA, Carlos Alberto. Arbitragem e processo: um comentário à Lei no 9.307/96. 2a . ed. São Paulo: Atlas, 2004, p. 265-271; CAHALI, Francisco José. Curso de arbitragem. São Paulo: RT, 2011, n. 10.2.2, p. 232-234; GUERRERO, Luís Fernando. Tutela de urgência e arbitragem. Revista Brasileira de Arbitragem,. Porto Alegre: Síntese, v. 6, n. 24, Curitiba: Comitê Brasileira de Arbitragem, 2009, p. 22-44; FIGUEIRA JÚNIOR, Joel Dias. Arbitragem, jurisdição e execução: análise crítica da Lei 9.307 /96, de 23.09.1996. São Paulo: RT, 1999, p. 222; AZEVEDO NETO, João Luiz Lessa de. Medidas cautelares, arbitragem e a cooperação com o poder judiciário. Execução e cautelar: estudos em homenagem a José de Moura Rocha. In: ADONIAS, Antonio Adonias; DIDIER JR., Fredie Didier Jr.; CUNHA, Leonardo Carneiro da Cunha (coords.). Execução e cautelar: estudos em homenagem a José de Moura Rocha. Salvador: JusPodivm, 2012, p. 263-281. 
Diante do autorregramento das partes quanto à arbitragem, há quem defenda ser possível haver limitações ou restrições, estabelecidas na convenção de arbitragem, ao poder do juízo arbitral para a apreciação e a concessão de medidas de urgência, de natureza cautelar ou antecipatória. A restrição pode ser total ou parcial, mas precisa ser expressa. ${ }^{24}$ Não havendo restrição, o poder cautelar do juízo arbitral é inequívoco. Há, por outro lado, quem entenda não ser possível qualquer restrição, por violar o direito ao livre acesso à jurisdição. ${ }^{25}$

Destaca-se a cooperação entre o juízo arbitral e o juízo estatal. Concedida a medida cautelar pelo juízo arbitral, este deve, mediante carta arbitral (Lei 9.307/1996, art. 22-C; CPC, art. 237, IV), solicitar o apoio do juízo estatal para impor sua efetivação ou cumprimento forçado pela parte.

\subsection{A arbitragem e a Administração Pública}

Tradicionalmente, sempre houve resistência para a arbitragem com o Poder Público. Ao longo da história do Brasil, formaram-se três correntes doutrinárias: (a) a que não admite arbitragem que envolva o Poder Público; (b) a que admite sempre, mesmo que não haja lei específica, sendo suficiente a própria lei da arbitragem; (c) a que admite, desde que haja lei específica para determinada atividade pública.

A primeira corrente funda-se na ideia de indisponibilidade do interesse público, enquanto a segunda defende que o interesse da Administração Pública não equivale ao interesse público. Já a terceira apoiase na necessidade de respeito ao princípio da legalidade.

As opiniões mais atuais dividem-se entre a segunda e a terceira correntes, havendo uma tendência de prevalecer a segunda. De todo modo, já há disposição expressa prevendo a arbitragem com o Poder Público. A Lei 9.307, de 1996, foi alterada pela Lei 13.129, de 2015, passando a contar, em seu art. $1^{\circ}$, com o $§ 1^{\circ}$ que assim dispõe: "A administração pública direta e indireta poderá utilizar-se da arbitragem para dirimir conflitos relativos a direitos patrimoniais disponíveis".

E, nos termos do $§ 2^{\circ}$ do art. $1^{\mathrm{o}}$ da Lei 9.307 , de 1996, igualmente acrescentado pela Lei 13.129, de 2015, "A autoridade ou o órgão competente da administração pública direta para a celebração de convenção de arbitragem é a mesma para a realização de acordos ou transações".

Já se viu, no item 2.2. supra, que há a arbitrabilidade subjetiva e a arbitrabilidade objetiva. A arbitrabilidade, que significa a possibilidade de um litígio ou de uma disputa submeter-se à arbitragem, pode referir-se à matéria (ratione materiae - arbitrabilidade objetiva) ou à pessoa (ratione personae arbitrabilidade subjetiva). ${ }^{26} \mathrm{O} \S 1^{\mathrm{o}}$ do art. $1^{\mathrm{o}}$ da Lei 9.307 , de 1996 , prevê expressamente a possibilidade de a Administração Pública valer-se da arbitragem para a solução de suas disputas. Há, portanto, arbitrabilidade subjetiva.

Quanto à arbitrabilidade objetiva, é preciso investigar quais os litígios cuja natureza é compatível com a arbitragem. Nesse sentido, cumpre observar se o litígio insere-se numa relação de Direito Privado ou numa relação de Direito Público. Como explica Ana Perestrelo de Oliveira, "A dicotomia é clássica e plena de consequências ao nível da arbitrabilidade da controvérsia. No primeiro caso, o ente público age desprovido de poderes de autoridade (acta jure gestionis), ao contrário do que sucede no segundo, em que atua com poderes de império (acta jure imperii)". ${ }^{27}$

O $\S 1^{\circ}$ do art. $1^{\circ}$ da Lei 9.307, de 1996, como já se viu, assim dispõe: "A administração pública direta e indireta poderá utilizar-se da arbitragem para dirimir conflitos relativos a direitos patrimoniais disponíveis”. O dispositivo menciona a disponibilidade e, igualmente, a patrimonialidade do direito. Há

24 CAHALI, Francisco José. Curso de arbitragem. São Paulo: RT, 2011Ob. cit., n. 10.2.3, p. 235-236; DINAMARCO, Cândido Rangel. A arbitragem na teoria geral do processo. São Paulo: Malheiros, 2013. Ob. cit., n. 88, p. 226-229.

25 FIGUEIRA JÚNIOR, Joel Dias. Arbitragem, jurisdição e execução: análise crítica da Lei 9.307/96, de 23.09.1996. São Paulo: RT, 1999. Ob. cit., p. 224-225; COSTA, Nilton César Antunes da. Poderes do árbitro. São Paulo: RT, 2002, p. 111; ROSA, José Carlos. Medidas cautelares e arbitragem. São Paulo: Opera Nostra, 2006, p. 104.

26 A eventual inarbitrabilidade da disputa determina a invalidade da convenção de arbitragem, sendo igualmente causa de anulação da sentença arbitral, nos termos do art. 32, I, da Lei 9.307, de 1996.

27 OLIVEIRA, Ana Perestrelo. Arbitragem de litígios com entes públicos. 2. ed. Coimbra: Almedina, 2015 , p. 15. 
uma arbitrabilidade ampla relativamente ao Poder Público quando este atua jure gestionis, ou seja, quando ele estiver inserido numa relação de Direito Privado. Quando, porém, a relação for pública, na qual houver manifesto exercício do poder de império, será preciso examinar o grau (in)disponibilidade do direito. Para que seja possível a arbitragem, deve haver disponibilidade e o direito deve ser patrimonial.

Antes mesmo do advento da Lei 13.129, de 2015, já havia vários diplomas normativos prevendo a arbitragem com entidades integrantes da Administração Pública, a exemplo de sociedades de economia mista e empresas públicas. Todos eles tratam de questões contratuais, não relacionadas com o exercício de atos de império, mas sim com direitos patrimoniais disponíveis.

A Lei 8.987, de 1995, que regula o regime de concessões e permissões de serviços públicos previstos no art. 175 da Constituição Federal, estabelece como cláusula essencial, portanto, obrigatória, necessária, a que diz respeito ao foro e ao modo amigável de solução das divergências contratuais (art. 23, XV), aplicandose a esses contratos administrativos também a Lei 8.666, de 1993.

A Lei 9.472, de 16 de julho de 1997, dispõe sobre a organização dos serviços de telecomunicações, cria a Agência Nacional de Telecomunicações - ANATEL, sob regime autárquico, no art. 93, e trata do contrato de concessão, do foro e do modo amigável para a solução extrajudicial dos conflitos contratuais.

A Lei 9.478, de 6 de agosto de 1997, dispõe sobre a política energética e cria a Agência Nacional do Petróleo, sob regime autárquico especial, e, ao tratar do contrato de concessão, especifica que, dentre as cláusulas essenciais, deve constar a que verse sobre a solução de controvérsias, relacionada com o contrato e sua execução, inclusive a conciliação e a arbitragem internacionais.

A Lei 10.233, de 5 de junho de 2001, que dispõe sobre os transportes aquaviário e terrestre, cria a Agência Nacional de Transportes Terrestres, a Agência Nacional de Transportes Aquaviários e o Departamento Nacional de Infraestrutura de Transportes, prevendo, como cláusula essencial do contrato de concessão, a solução de controvérsias relacionadas com o contrato e sua execução, inclusive a conciliação e a arbitragem.

A Lei 10.343, de 24 de abril de 2002, cria o Mercado Atacadista de Energia Elétrica, prevendo a arbitragem para a solução de controvérsias.

A Lei 11.079, de 30 de dezembro de 2004, que institui normas gerais para licitação e contratação de parceria público-privada no âmbito da Administração Pública, dispõe, em seu art. 11, III, que o instrumento convocatório conterá minuta do contrato, indicará expressamente a submissão da licitação às normas ali previstas, podendo ainda prever o emprego dos mecanismos privados de resolução de disputas, inclusive a arbitragem, a ser realizada no Brasil e em língua portuguesa, nos termos da lei de arbitragem, para dirimir conflitos decorrentes ou relacionados ao contrato.

Nesse mesmo sentido, o $\$ 1^{\circ}$ do art. 62 da Lei 12.815, de 2013, dispõe que, para resolver litígios decorrentes do inadimplemento, pelas concessionárias, arrendatárias, autorizatárias e operadoras portuárias quanto ao recolhimento de tarifas portuárias ou outras obrigações financeiras perante a administração do porto e a ANTAQ, poderá ser utilizada a arbitragem, nos termos da Lei 9.307, de 1996.

A Lei 13.800, de 2019, que autoriza a Administração Pública a firmar instrumentos de parceria e termos de execução de programas, projetos e demais finalidades de interesse público com organizações gestoras de fundos patrimoniais, estabelece, no $\S 6^{\circ}$ de seu art. 26, que, havendo previsão, no instrumento de parceria, de compromisso arbitral, a resolução de controvérsias entre a instituição pública federal apoiada, a organização gestora de fundo patrimonial e a organização executora poderá ser conduzida pela Câmara de Conciliação e Arbitragem da Administração Federal da Advocacia-Geral da União.

A Lei 13.867, de 2019, acrescentou os arts. 10-A e 10-B ao Decreto-lei 3.365, de 1941, passando a prever a possibilidade de arbitragem em casos de desapropriação. Feita a opção pela via arbitral, o particular indicará um dos órgãos ou instituições especializados em arbitragem previamente cadastrados pelo órgão responsável pela desapropriação. A arbitragem, nesse caso, seguirá as normas da Lei 9.307, de 1996 (Lei de Arbitragem) e, subsidiariamente, os regulamentos do órgão ou instituição responsável.

Há, como se percebe, várias leis autorizando a arbitragem com entidades integrantes da Administração Pública. Ao lado dessas leis, a própria lei da arbitragem contém a previsão específica que permite sua 
instauração envolvendo o Poder Público. Basta que haja arbitrabilidade objetiva e arbitrabilidade subjetiva.

Destaca-se um julgamento paradigmático do Supremo Tribunal Federal que enfrentou essa questão e admitiu a possibilidade de arbitragem que envolva o Poder Público. Com efeito, ao julgar o Agravo de Instrumento 52.181, a Suprema Corte entendeu pela "legalidade do juízo arbitral, que o nosso direito sempre admitiu e consagrou, até mesmo nas causas contra a Fazenda", concluindo haver "legitimidade da cláusula de irrecorribilidade de sentença arbitral, que não ofende a norma constitucional”. ${ }^{28}$

A doutrina vem se posicionando no sentido de admitir a arbitragem que envolva o Poder Público. Ao julgar o Recurso Especial 904.813/PR, o Superior Tribunal de Justiça anotou que "Tanto a doutrina como a jurisprudência já sinalizaram no sentido de que não existe óbice na estipulação da arbitragem pelo poder público, notadamente pelas sociedades de economia mista, admitindo como válidas as cláusulas compromissórias previstas em editais convocatórios de licitação e contratos”. E, ainda segundo se registrou em tal julgado, "o fato de não haver previsão da arbitragem no edital de licitação ou no contrato celebrado entre as partes não invalida o compromisso arbitral firmado posteriormente". ${ }^{29}$

Enfim, é possível a arbitragem que envolva entes integrantes da Administração Pública. Para que o ente público celebre convenção arbitral, não é preciso, porém, que haja previsão no edital de licitação. ${ }^{30}$

A Administração Pública pode submeter suas disputas a uma arbitragem, podendo esta ser ad hoc ou institucional. ${ }^{31}$

Há, entretanto, algumas adaptações que devem ser feitas. A Administração Pública, de qualquer dos poderes, está submetida aos princípios previstos no art. 37 da Constituição Federal, a saber: legalidade, moralidade, publicidade, impessoalidade e eficiência.

Diante disso, a arbitragem que envolva o Poder Público não pode ser sigilosa, nem confidencial, em razão da necessidade de observância ao princípio da publicidade. Além disso, em virtude do princípio da legalidade, a doutrina entende que não é possível arbitragem por equidade, quando o Poder Público figurar como uma das partes envolvidas; só é possível a arbitragem por legalidade.

Exatamente por isso, o $§ 3^{\circ}$ do art. $2^{o}$ da Lei 9.307 , de 1996, assim dispõe: "A arbitragem que envolva a administração pública será sempre de direito e respeitará o princípio da publicidade”. Significa que não pode haver arbitragem por equidade com o Poder Público, nem ela pode ser confidencial ou regida pelo sigilo. Só é possível haver com a Fazenda Pública arbitragem por legalidade, respeitando-se o princípio da publicidade.

A Lei 12.527, de 2011, regula o acesso à informação, garantindo a qualquer interessado a apresentação de pedido de acesso a informações a órgãos e entidades da Administração direta e indireta da União, dos Estados, dos Municípios e do Distrito Federal. A obtenção de informações que digam respeito a alguma arbitragem que envolva o Poder Público deve ser requerida diretamente à própria Administração, e não ao tribunal arbitral ou ao órgão ou entidade onde tramite o procedimento arbitral ${ }^{32}$. $\mathrm{O}$ dever de cumprir com a publicidade é da Administração Pública, e não do tribunal arbitral ou do órgão ou entidade onde tramite a arbitragem. Cabe à Administração receber, processar e responder aos pedidos de acesso à informação, devendo fornecer a informação ou negar o fornecimento com base no sigilo ou limitação pública de acesso.

28 STF, Pleno, AI 52.181, Rel. Min. Bilac Pinto, j. 14.11.1973, DJ15.02.1974, p. 720.

29 STJ, 3ㅜㅡㄹ Turma, REsp 904.813/PR, Rel. Min. Nancy Andrighi, j. 20.10.2011, DJe 28.02.2012.

$30 \quad$ Nesse sentido, o enunciado 571 do Fórum Permanente de Processualistas Civis: "A previsão no edital de licitação não é pressuposto para que a Administração Pública e o contratado celebrem convenção arbitral”.

$31 \quad$ Nesse sentido, o enunciado 572 do Fórum Permanente de Processualistas Civis: “A Administração Pública direta ou indireta pode submeter-se a uma arbitragem ad hoc ou institucional”.

32 Nesse sentido, o enunciado 128 do Fórum Nacional do Poder Público: "O juízo arbitral não se subordina aos pedidos de informação realizados com base na Lei 12.527/2011, quando a Administração Pública for parte no processo arbitral, fundado em razões que justifiquem a limitação de acesso à informação”. 
Por ser necessário respeitar o princípio da publicidade, já há quem defenda que as sentenças arbitrais, em arbitragens que envolvem o Poder Público, devem ser publicadas e divulgados, sendo igualmente necessário que haja um sistema, amplamente divulgado, de precedentes das câmaras arbitrais ${ }^{33}$.

É preciso, porém, compatibilizar o princípio da publicidade com as hipóteses de sigilo previstas em lei, que resguardam a segurança nacional (como, por exemplo, nas hipóteses previstas na Lei 12.527, de 2011). Bem por isso, nos termos do enunciado 104 do Fórum Nacional do Poder Público: "Na arbitragem com a Administração Pública, a publicidade dos atos e documentos do processo está sujeita à mitigação em função dos casos de sigilo previstos em lei”. Também por isso, consoante anotado no enunciado 105 do Fórum Nacional do Poder Público: "Caracteriza-se boa prática da Administração Pública dar conhecimento ao tribunal arbitral e à parte adversa do recebimento de pedido de acesso à informação com fundamento na Lei 12.527/2011, relacionado a procedimento arbitral do qual seja parte”.

O respeito à legalidade e à publicidade relaciona-se com a necessidade de viabilizar o controle dos atos públicos. É por isso que, para que se elimine qualquer resistência à adoção de arbitragem pelo Poder Público, há quem defenda a necessidade de envolver os tribunais de contas na arbitragem, permitindo que haja maior aproximação entre os tribunais arbitrais e a jurisprudência firmada pelos tribunais de $\operatorname{contas}^{34}$.

A Administração Pública, por causa dos princípios da impessoalidade e da moralidade, deve contratar bens e serviços mediante licitação. A escolha do juízo ou tribunal arbitral deve ser submetida ao procedimento licitatório? Não tem prevalecido o entendimento de que seria necessária a realização de licitação. Há, de um lado, quem defenda que se trata de caso de inexigibilidade de licitação, ${ }^{35}$ cujas hipóteses legais são exemplificativas, e não exaustivas. Há, por outro lado, quem afirme que não se aplicam as normas sobre licitação à escolha da câmara arbitral. ${ }^{36}$

A sentença arbitral proferida contra Fazenda Pública não está sujeita à remessa necessária ${ }^{37}$. O art. 496 do CPC, que disciplina a remessa necessária, aplica-se apenas ao ambiente do processo judicial, não tendo incidência relativamente ao processo arbitral. As demais prerrogativas da Fazenda Pública em juízo não se apresentam, em regra, na arbitragem. Não há intimação pessoal, nem prazos em dobro, a não ser que as partes assim prevejam no compromisso ou no termo de arbitragem. Se nada disserem, a regra é o ente público não gozar de suas prerrogativas processuais.

Ao lado disso tudo, uma sentença arbitral que imponha uma condenação pecuniária ao Poder Público deve acarretar a expedição de precatório, em razão do que dispõe o art. 100 da Constituição Federal, regra que não pode ser afastada, ainda que se trate de arbitragem ${ }^{38}$. Se a condenação for de pequeno valor, não se expede precatório, mas Requisição de Pequeno Valor - RPV, a ser paga em sessenta dias, nos termos da legislação de regência. Só não haverá necessidade de precatório ou de RPV, se o ente que integra a Administração Pública for uma sociedade de economia mista ou uma empresa pública, cujo regime jurídico é de direito privado, não estando sujeitas ao precatório.

Com essas ressalvas e adaptações, admite-se a arbitragem que envolve entes da Administração Pública.

\section{A mediação e a conciliação no Brasil}

\footnotetext{
33 SARAIVA, Leonardo. Arbitragem na Administração Pública. Rio de Janeiro: Lumen Juris, 2019, n. 3.4.1, p. 100-108.

34 SARAIVA, Leonardo. Ob. cit., n. 3.4.1, p. 108.

35 AMARAL, Paulo Osternack. Arbitragem e Administração Pública. Belo Horizonte: Fórum, 2012, p. 75.
}

36 BONÍCIO, Marcelo José Magalhães. Breve análise sobre a arbitragem em conflitos que envolvem o Estado. Revista da Procuradoria Geral do Estado de São Paulo. São Paulo, v. 75, p. 13-20, 2012. Nesse sentido, o enunciado 103 do Fórum Nacional do Poder Público: "A escolha da câmara arbitral e a indicação de árbitro pela Administração Pública não se sujeitam ao regime jurídico em matéria de licitações e contratos administrativos”.

37 Nesse sentido, o enunciado 164 do Fórum Permanente de Processualistas Civis: "A sentença arbitral contra a Fazenda Pública não está sujeita à remessa necessária”. No mesmo sentido, o enunciado 117 do Fórum Nacional do Poder Público: "A sentença arbitral não enseja a remessa necessária”.

38 Nesse sentido, o enunciado 101 do Fórum Nacional do Poder Público: "O cumprimento da sentença arbitral de obrigação de pagar quantia certa pela Fazenda Pública deve seguir a ordem cronológica de apresentação dos precatórios”. 


\subsection{Observação introdutória}

A legislação processual civil atribuía ao juiz o dever de tentar obter a autocomposição pelas partes, conciliando-as. A experiência demonstrou que tal opção não é adequada, por vários motivos.

Primeiro, o juiz foi formado para julgar, não tendo preparação satisfatória para adoção das técnicas de convencimento ou de ajuda à obtenção da autocomposição.

Segundo, o juiz tem suas preocupações voltadas para os julgamentos e as prolações das decisões a seu cargo, não reunindo condições de tempo para as tentativas de autocomposição.

Terceiro, o ambiente da sala de audiência, que ostenta símbolos formais que intimidam, não se revela adequado nem satisfatório para convencer as partes a uma autocomposição.

Quarto, não é igualmente adequado aglutinar a função de conciliador e de julgador, pois muitas das informações prestadas na sessão de conciliação influenciam o convencimento, eliminando o sigilo e a confidencialidade que são relevantes para que se tente obter a autocomposição.

Quinto, não há distinção satisfatória entre conciliação e mediação, não sendo utilizadas as técnicas corretas para cada caso específico.

\subsection{A Resolução 125/2010 do Conselho Nacional da Justiça - CNJ - e a política pública de mediação e conciliação}

O Conselho Nacional de Justiça, por meio da Resolução 125, de 2010, dispõe sobre a política judiciária nacional de tratamento adequado dos conflitos de interesses no âmbito do Poder Judiciário.

Nos termos da citada resolução, cabe aos órgãos judiciários oferecer mecanismos de solução de controvérsias, em especial os chamados meios consensuais, como a mediação e a conciliação, além de prestar atendimento e orientação ao cidadão.

Na implementação dessa política judiciária nacional, serão observadas a centralização das estruturas judiciárias, a adequada formação e treinamento de servidores, conciliadores e mediadores, bem como o acompanhamento estatístico específico. $\mathrm{O}$ CNJ auxiliará os tribunais na organização dos serviços de mediação e conciliação, podendo ser firmadas parcerias com entidades públicas e privadas.

A política nacional instituída pela mencionada resolução procura conferir tratamento adequado aos conflitos de interesses no âmbito do Poder Judiciário, preocupando-se com a qualidade dos serviços a serem oferecidos. Daí por que há regras explícitas sobre a capacitação dos mediadores e conciliadores.

A disciplina contida na Resolução 125, de 2010, do CNJ denota que a conciliação e a mediação devem ser organizadas com a finalidade não de solucionar a crise de morosidade da Justiça, mas como um método para se dar tratamento mais adequado aos conflitos de interesses que ocorrem na sociedade. ${ }^{39}$

Tais meios são adequados para solução de controvérsias. O problema é que, tradicionalmente, estabeleceuse, no Brasil, um excesso de litigância ou uma judicialização dos conflitos, acarretando uma quantidade avassaladora de processos instaurados perante o Poder Judiciário. Só que, muitas vezes, a solução adjudicada pelo juiz estatal não é a mais adequada, com resultados insatisfatórios. É preciso estimular e orientar as pessoas a resolverem, por si próprias, seus conflitos, devendo o Judiciário, em algumas hipóteses, ser o meio alternativo. ${ }^{40}$

O CPC incorporou as normas contidas na Resolução 125, de 2010, do CNJ, trazendo diversos dispositivos relacionados com os chamados "meios alternativos de resolução de disputas" (ADR - Alternative Dispute Resolution Methods).

39 WATANABE, Kazuo. Política judiciária nacional de tratamento adequado dos conflitos de interesses: utilização dos meios alternativos de resolução de controvérsias. O processo em perspectiva: jornadas brasileiras de direito processual. São Paulo: RT, 2013, p. 243.

40 CÂMARA, Alexandre Freitas. Mediação e conciliação na Res. 125 do CNJ e no projeto de Código de Processo Civil. O processo em perspectiva: jornadas brasileiras de direito processual. São Paulo: RT, 2013, p. 40. 


\subsection{Os ADRs no CPC}

Ao mesmo tempo que incentiva, o CPC institucionaliza os ADRs, disciplinando-os, na realidade, não como meios "alternativos" de resolução de disputas, mas como meios "integrados". Com efeito, ao tratar da mediação e da conciliação, o projeto prevê sua realização no processo judicial, sem, todavia, eliminar sua independência e flexibilidade, criando, ademais, instrumentos de comunicação e de troca cooperativa com a arbitragem, como a carta arbitral.

Há, no Código, uma valorização do consenso e uma preocupação em criar no âmbito do Judiciário um espaço não apenas de julgamento, mas de resolução de conflitos. Isso propicia um redimensionamento e democratização do próprio papel do Poder Judiciário e do modelo de prestação jurisdicional pretendido. O distanciamento do julgador e o formalismo típico das audiências judiciais, nas quais as partes apenas assistem ao desenrolar dos acontecimentos, falando apenas quando diretamente questionadas em um interrogatório com o objetivo de obter sua confissão, são substituídos pelo debate franco e aberto, com uma figura que pretende facilitar o diálogo: o mediador ou o conciliador.

Além de propiciar um redimensionamento e democratização do próprio papel do Poder Judiciário e do modelo de prestação jurisdicional pretendido, o projeto contribui para ampliar o acesso democrático à justiça, pois, como esclarecem Dierle Nunes e Ludmila Teixeira, "o acesso à justiça democrático exige que as autonomias dos cidadãos sejam respeitadas não somente no momento da gênese do direito, mas sobretudo no momento aplicativo". ${ }^{41}$

O CPC cria um sistema integrado de resolução de disputas. Há uma importante mudança de conceito e orientação: o foco deixa de estar (apenas) no julgamento e passa para a efetiva solução do conflito.

Logo no início, quando disciplina as normas fundamentais do processo civil, o CPC contém disposições informadoras de um modelo processual cooperativo, estabelecendo que os sujeitos processuais devem cooperar para o julgamento do processo, cabendo ao juiz velar pelo contraditório e pela paridade das partes.

$\mathrm{O}$ art. $3^{\circ}$ do CPC trata exatamente do princípio da inafastabilidade (reproduzindo o quanto previsto no art. 5 ${ }^{\underline{o}}, \mathrm{XXXV}$, da Constituição Federal), contemplando, em seus parágrafos, a admissibilidade da arbitragem e estabelecendo a promoção dos meios consensuais de resolução de disputas como um dos pilares do processo civil brasileiro.

Efetivamente, caberá aos magistrados, advogados e membros do Ministério Público, inclusive no curso do processo judicial, estimular o uso da conciliação, da mediação e dos demais mecanismos consensuais de resolução de conflitos, sendo dever do Estado promover a solução consensual dos conflitos.

A norma é promocional. O Estado deverá promover o uso dos ADR's, e os profissionais da área jurídica deverão estimular o seu uso. Isso inclui um esforço de capacitação de pessoal, criação de estrutura física, esclarecimento da população e treinamento dos servidores e dos profissionais do meio jurídico em geral. Não apenas estimula o uso da ADR em âmbito judicial, mas o projeto também estabelece que a União, os Estados, o Distrito Federal e os Municípios deverão criar câmaras de mediação e conciliação, com atribuições relacionadas à solução consensual de conflitos no âmbito administrativo. Assim, há a construção de um verdadeiro sistema de resolução de disputas, composto pelo Poder Judiciário e por instituições públicas e privadas dedicadas ao desenvolvimento de mediação, conciliação e arbitragem.

Por outro lado, abrem-se novas possibilidades de atuação para as profissões jurídicas: os advogados e defensores públicos terão de oferecer aos seus clientes opções e caminhos possíveis para a solução do seu conflito, dentro do dever profissional de esclarecimento.

Da leitura do CPC observa-se que os meios alternativos de resolução de disputa deixam de ser apenas alternativos, passando a compor um quadro geral dos meios de resolução de disputas; passam a ser meios integrados de resolução de disputas. A dicotomia (resolução judicial x meios alternativos) fica atenuada. Não se fala mais no meio de resolução de disputas e suas alternativas, mas se oferece uma série de meios, 
entrelaçados entre si e funcionando num esquema de cooperação, voltados à resolução de disputas e pacificação social.

O objetivo do processo não é simplesmente julgar, mas resolver disputas. Isso, muitas vezes, significa uma sentença bem fundamentada, com uma fase de execução ágil e efetiva, mas, em outras, é alcançar o meiotermo e o acordo entre as partes. Trata-se de uma importante mudança de paradigma. Tradicionalmente, desde Chiovenda e Carnelutti, sempre se falou que o processo serve para aplicar a lei, sendo um espaço de decisão e raciocínio subsuntivo. O processo civil brasileiro entrará na fase do processo como local de diálogo e de busca pelo melhor caminho para a resolução de cada disputa.

Cappelletti e Garth colocam a promoção dos meios alternativos de resolução de disputas na terceira onda de acesso à justiça, ${ }^{42}$ justamente por eles permitirem um menor formalismo e maior proximidade das partes; esse parece ser o caminho a ser trilhado pelo Brasil.

\subsection{A mediação e a conciliação}

A mediação e a conciliação não devem ser encaradas como medidas destinadas a desafogar o Poder Judiciário, mas como o melhor e mais adequado meio de resolução de disputas. Há disputas que são melhor e mais adequadamente resolvidas pela mediação, enquanto há outras que se resolvem mais apropriadamente pela conciliação, sendo certo que há outras ainda que só se resolvem mais adequadamente pelo julgamento realizado por um juiz.

A mediação e a conciliação não devem ser encaradas como alternativas a quem não foi bafejado com as melhores condições de aguardar um desfecho demorado de um processo judicial. Constituem, na realidade, medidas aptas e adequadas a resolver conflitos em determinados casos. Há, efetivamente, casos que são mais bem resolvidos por esses meios.

A conciliação e a mediação constituem técnicas que se destinam a viabilizar a autocomposição de disputas ou litígios. Nelas, um terceiro intervém, contribuindo para que as partes componham por si mesmas a disputa que há entre elas.

A conciliação e a mediação não se confundem com a arbitragem. Esta é um meio de heterocomposição. O árbitro, assim como o juiz, decide a causa que lhe é submetida. Na conciliação e na mediação, o terceiro é convocado, não para decidir, mas para contribuir com as partes, a fim de que estas, por si, cheguem a uma solução, mediante autocomposição.

A Lei 13.140, de 2015, disciplina a mediação entre particulares e a autocomposição de conflitos no âmbito da Administração Pública. A mediação consiste num meio destinado à obtenção de autocomposição. $\mathrm{O}$ mediador intermedeia as partes, auxiliando-as para que cheguem a uma solução consensual do conflito. O mediador nada decide; apenas conduz as partes, mediante técnicas adequadas, para que elas tenham melhores condições de dar uma solução à disputa.

Não há, na mediação, qualquer caráter jurisdicional, não sendo conferido ao mediador poder de decidir ou de impor qualquer medida às partes. De igual modo, as partes não estão sujeitas a qualquer supremacia ou poder exercido pelo mediador.

O parágrafo único do art. $1^{\circ}$ da Lei 13.140, de 2015, definiu a mediação como "a atividade técnica exercida por terceiro imparcial sem poder decisório, que, escolhido ou aceito pelas partes, as auxilia e estimula a identificar ou desenvolver soluções consensuais para a controvérsia”. O texto normativo faz constar da definição elementos como "terceiro imparcial", "sem poder decisório", que "auxilia e estimula" as partes "a identificar ou desenvolver soluções consensuais para a controvérsia".

O mediador, como se percebe, é um facilitador do diálogo: ${ }^{43}$ as partes envolvidas são por ele auxiliadas em sua comunicação para que possam encontrar respostas adequadas ao impasse que encontram na solução de sua disputa.

42 CAPPElletTi, Mauro; GARTH, Bryant. Acesso à justiça. Porto Alegre: Sérgio Antonio Fabris, 1988, p. 68-71.

43 TARTUCE, Fernanda. Mediação nos conflitos civis. 2. ed. São Paulo: Método, 2015, n. 1.3.2.3.2.2, p. 52. 
Além de elementos comuns a várias definições apresentadas pela doutrina, merece destaque a indicação, contida no referido dispositivo legal, segundo a qual a mediação é uma atividade técnica. Quer isso dizer que a mediação há de ser realizada por pessoa habilitada a tanto, independentemente de sua formação anterior. O mediador não precisa, necessariamente, ter formação jurídica, mas deve ter habilidade para exercer a atividade e deve, ainda, gozar da confiança mútua das partes.

A mediação é atividade que pode ser exercida por profissionais das mais diferentes áreas, sendo, a depender do caso, até mesmo recomendável a participação de dois ou mais mediadores, de diferentes áreas ou formações acadêmicas, que possam contribuir para a busca do consenso entre as partes. ${ }^{44} \mathrm{E}$ preciso, porém, que sejam todas capacitadas a exercer a atividade de mediação. ${ }^{45}$

Nas mediações extrajudiciais, os mediadores devem ser capacitados e gozar da confiança mútua das partes, não sendo necessário seu registro em cadastro de mediadores do Tribunal ou de Câmara de Mediação aceita pelos Tribunais. ${ }^{46}$ Já os mediadores judiciais precisam, conforme exigência do art. 167 do CPC, estar inscritos em cadastro nacional e em cadastro do tribunal, preenchendo requisito de capacitação mínima, por meio de curso realizado por entidade credenciada nos termos definidos pelo CNJ. E, segundo exigência contida no art. 11 da Lei 13.140, de 2015, o mediador judicial deve, ainda, ser graduado há pelo menos dois anos em curso de ensino superior.

De todo modo, as partes têm a garantia de, mesmo na mediação judicial, poder escolher um mediador de sua confiança, ainda que não esteja cadastrado no tribunal. Não havendo consenso sobre quem deva ser o mediador, aí haverá, então, distribuição do caso entre os que estão cadastrados junto ao tribunal (CPC, art. 168).

A Lei 13.140, de 2015, trata da mediação e da atividade do mediador, disciplinando tanto a mediação judicial como a extrajudicial. Já o Código de Processo Civil menciona tanto a conciliação como a mediação, traçando diferenças entre elas.

Não há distinção precisa entre a mediação e a conciliação. O Código de Processo Civil estabeleceu distinção legal entre elas.

Assim, pelo critério legal, a mediação é medida mais adequada aos casos em que tiver havido vínculo anterior entre as partes, a exemplo do que ocorre em matéria societária e de direito de família. O mediador tem a função de auxiliar os interessados a compreender as questões e os interesses em conflito, de modo que eles possam, pelo restabelecimento da comunicação, identificar, por si próprios, soluções consensuais que gerem benefícios mútuos. Para tanto, o mediador vale-se de técnicas próprias, com diálogo, paciência, simplicidade e constante esclarecimento.

Por sua vez, ainda pelo critério legal, o conciliador deve atuar preferencialmente nos casos em que não tenha havido vínculo anterior entre as partes, como, por exemplo, em acidentes de veículo ou em casos de danos extrapatrimoniais em geral. O conciliador pode sugerir soluções para o litígio, sendo vedada a utilização de qualquer tipo de constrangimento ou intimidação para que as partes conciliem.

Cotejando-se o $\S 1^{\circ}$ com o $\S 2^{o}$, ambos do art. 165 do CPC, tem-se a impressão de que o mediador não sugere qualquer solução para o conflito; só quem poderia fazer sugestões seria o conciliador. Ocorre, porém, que o inciso III do $\$ 1^{\circ}$ do art. 30 da Lei 13.140, de 2015, menciona a "manifestação de aceitação de proposta de acordo apresentada pelo mediador", numa clara indicação de que o mediador pode também fazer sugestões ou apresentar proposta de acordo para as partes se autocomporem.

A legislação brasileira é a única a fazer essa diferença entre mediador e conciliador. Na verdade, a diferença estaria nas técnicas utilizadas. Só que a intermediação de uma autocomposição usa técnicas variadas, a depender da postura das partes envolvidas, do grau de mágoas recíprocas entre elas, do nível de conhecimento que têm, do perfil psicológico, a revelar a existência de maior ou menor ansiedade na solução do problema etc. Em casos em que haja vínculo anterior, é natural haver mágoas ou maiores

44 COELHO, Renata Moritz Serpa. Atualidades sobre a mediação de conflitos no Brasil a partir de 2015. Revista de Processo. São Paulo: RT, v. 272, out.-2017, p. 458.

45 COELHO, Renata Moritz Serpa. Ob. cit., p. 458.

46 VASCONCELOS, Carlos Eduardo de. Mediação de conflitos e práticas restaurativas. 4. ed. São Paulo: Método, 2015, p.

115 . 
sentimentos envolvidos, mas as técnicas destinadas a eliminar essas mágoas e angústias ou a diminuir sentimentos recíprocos que repulsa e animosidade podem ser utilizadas também em casos em que não se verifique vínculo anterior entre as partes, mas estas têm perfil psicológico que exige a adoção daquelas técnicas.

Tudo está, portanto, a depender do tipo de problema e, sobretudo, do perfil dos envolvidos na disputa. De todo modo, não há como recusar a existência de textos normativos que impõem a diferença entre a mediação e a conciliação, estabelecendo diversas técnicas contributivas para a obtenção da autocomposição.

A Lei 13.140, de 2015, trata apenas da mediação, não mencionando a conciliação. Suas regras devem aplicar-se igualmente à conciliação, pois as diferenças entre mediação e conciliação não são tão acentuadas, variando a adoção de algumas técnicas, a depender das pessoas envolvidas e do objeto da disputa havida entre elas.

O CPC prevê, em seu art. 166, que "a conciliação e a mediação são informadas pelos princípios da independência, da imparcialidade, da autonomia da vontade, da confidencialidade, da oralidade, da informalidade e da decisão informada”.

Conjugando-se o disposto no art. 166 do CPC com a disposição contida no art. 2º da Lei 13.140, de 2015, observa-se que a atuação do mediador há de ser conduzida pelos princípios da independência, da imparcialidade, da isonomia entre as partes, da oralidade, da informalidade, da autonomia da vontade das partes, da busca do consenso, da confidencialidade, da boa-fé e da decisão informada.

Merece destaque a confidencialidade. As partes precisam estar à vontade para expor todos seus dramas, objetivos, expectativas, confiando no conciliador ou no mediador a condução segura, discreta e serena dos trabalhos destinados à obtenção de uma autocomposição. A confidencialidade, nos termos do $§ 1^{\circ}$ do art. 166 do CPC, "estende-se a todas as informações produzidas no curso do procedimento, cujo teor não poderá ser utilizado para fim diverso daquele previsto por expressa deliberação das partes”.

O que for narrado, conversado, discutido mantém-se em sigilo, não podendo ser divulgado pelo conciliador ou mediador, nem utilizado por qualquer das partes como argumento ou defesa em eventual disputa judicial posterior, caso frustradas as tentativas de autocomposição pelas partes. O conciliador e o mediador têm dever de sigilo, não podendo, inclusive, divulgar ou depor em juízo, seja como parte, seja como testemunha, sobre o que lhes foi confidenciado nas sessões realizadas com as partes. O dever de sigilo estende-se aos membros das equipes do conciliador ou mediador.

O conciliador ou mediador deve ser imparcial diante dos envolvidos, não podendo ter interesse no resultado em favor de qualquer deles. A aplicação de técnicas negociais pelo conciliador ou mediador, com o objetivo de proporcionar ambiente favorável à autocomposição, não ofende o dever de imparcialidade.

O mediador ou conciliador deve atuar com independência, para bem desempenhar suas funções, respeitando a autonomia da vontade das partes, inclusive no que respeita à definição das regras procedimentais.

A autonomia da vontade deve ser respeitada, reservando-se um espaço destinado para que os interessados possam decidir assuntos de seu interesse e construir a solução do seu conflito, sob a coordenação do conciliador ou mediador, cuja intervenção deve facilitar o restabelecimento da comunicação entre eles.

Pelo princípio da decisão informada, os interessados devem receber informações quantitativas e qualitativas sobre a composição que podem realizar, sendo advertidos das possíveis implicações e dos riscos a serem assumidos. É necessário, enfim, que os interessados sejam bem informados para que não sejam surpreendidos por qualquer consequência inesperada da solução pela qual venham a optar.

Tudo deve realizar-se em ambiente informal, leve, com linguagem simples e de fácil compreensão, sem roupas solenes ou símbolos que inibam os interessados, transmitindo-lhes conforto e confiança, com respeito à oralidade e ao diálogo entre todos. É nesse ambiente que cabe ao conciliador ou mediador tranquilizar os envolvidos, demonstrando que é normal haver um conflito, devendo ser igualmente normal resolvê-lo da melhor forma possível. 
O art. 165 do CPC estabelece que os tribunais criarão centros voltados à solução consensual de conflitos. Esses centros terão uma função dúplice. Eles serão responsáveis pela realização de sessões e audiências de conciliação e mediação, e deverão desenvolver programas destinados a auxiliar, orientar e estimular a autocomposição. Logo se nota uma preocupação na difusão dos mecanismos alternativos de resolução de disputas.

Os centros judiciais e as entidades privadas que se dediquem a essa atividade serão o local próprio para as atividades de mediação e conciliação que apenas de modo excepcional, poderão ser desenvolvidas em juízo, mas conduzidas por um mediador ou conciliador habilitado. Isso reforça a ideia de um "fórum multiportas" de resolução de litígio, contando tanto com varas tradicionais quanto com espaços adequados à mediação e à conciliação. O objetivo é criar um ambiente menos formal e mais adequando para a resolução consensual das desavenças.

A mediação e a conciliação não serão, como regra, conduzidas pelo magistrado, evidentemente que as partes podem transigir durante a fase de instrução do processo, e o magistrado, em uma atuação cooperativa, deve estimular o diálogo e facilitar a conciliação, mas haverá um profissional específico e devidamente qualificado para atuar no desenvolvimento da resolução consensual da disputa.

Isso é salutar, pois, na presença do magistrado, que julgará impositivamente o conflito, as partes não podem falar abertamente, sob pena de, em alguma medida, minar a sua estratégia jurídica para a fase do contencioso. ${ }^{47}$

O juiz deve sempre estimular a conciliação (inclusive na audiência de instrução - CPC, art. 359), embora essa atividade deva ser, por excelência, desenvolvida por um conciliador ou mediador habilitado. A preocupação do CPC é assegurar a imparcialidade do juiz e permitir um diálogo mais franco e flexível das partes nos esforços de autocomposição, já que o juiz que conduzir ativamente uma mediação ou conciliação pode, em alguma medida, acabar influenciado em seu julgamento pelas tratativas frustradas e pelo que for dito pelas partes no esforço de resolução amigável. ${ }^{48}$

Os $\S \S 3^{\circ}$ e $4^{\circ}$ do artigo 166 do CPC definem o papel do mediador e do conciliador. Tal definição seria desnecessária, já que a diferença entre as técnicas é bem trabalhada pela doutrina, mas mostra uma preocupação com a afirmação das técnicas no projeto, dada sua importância no contexto ali considerado.

O mediador e o conciliador judicial são tratados no CPC como auxiliares da justiça. Os tribunais poderão, se desejarem, promover concurso público para o provimento de cargos próprios de conciliador e mediador, mas manterão sempre uma lista das câmaras privadas de mediação e conciliação e uma relação de mediadores que atuarão nos centros de mediação e conciliação judiciais. A iniciativa é boa e visa a preparar pessoal devidamente habilitado e qualificado para essas atividades.

Os mediadores e conciliadores que atuem nos centros de mediação e conciliação judiciais e que sejam advogados de formação estarão impedidos de advogar junto ao tribunal a que esteja vinculado o centro em que atuem. Tal restrição, evidentemente, não se aplica aos advogados que desejarem desenvolver atividades de mediação e conciliação em seus escritórios ou em instituições privadas dedicadas a essas atividades, mesmo que essas instituições sejam cadastradas junto a qualquer tribunal.

Sempre será possível, também, que as partes escolham qualquer terceiro (advogado, inclusive) para atuar como mediador ou conciliador em seu caso, independentemente de qualquer cadastro ou formalidade junto ao tribunal. Aqui vige plenamente a autonomia da vontade das partes e a flexibilidade, que são inerentes aos mecanismos consensuais de resolução de disputas.

Deve haver uma preferência pela flexibilidade e informalidade, para a construção do diálogo. A conciliação ou mediação não precisa sequer ocorrer no ambiente judiciário, podendo, se as partes preferirem ou caso se sentirem mais à vontade, ser realizada no escritório de um dos advogados ou em outro ambiente. Deve sempre ser permitida a realização da audiência (encontro) fora do ambiente judiciário. Como o foco está na superação do dissenso, há o "empoderamento" das partes sobre os

47 SANDER, Frank. Varieties of dispute processing. In: LEVIN, A. Leo; WHEELER, Russell R. The pound conference: perspectives on justice in the future. Saint Paul: West Publishing Co., 1979, p. 75.

48 GOUVEIA, Mariana França. Curso de resolução alternativa de litígios. Coimbra: Almedina, 2011, p. 83-87. 
conflitos, de meros expectadores do litígio conduzido pelos advogados e pelo magistrado, as partes passam a atores importantes de sua solução.

Todo o processo de mediação e conciliação será sigiloso, como já ocorre nas mediações e conciliações privadas. Nenhuma das alegações das partes, o teor das conversas e dos documentos eventualmente produzidos no esforço para a composição poderão ser disponibilizados a terceiros ou utilizados para fins de instrução em processo judicial. O objetivo é criar um ambiente de franqueza nas negociações e discussões; não pode haver debate franco e acertamento de interesse caso o julgamento puder basearse no que for dito. De outro modo, a discussão seria falseada pela estratégia jurídica traçada para a vitória na fase litigiosa, impedindo a negociação, não se estabelecendo um mínimo de franqueza entre as partes.

O objetivo de uma solução consensual não é aplicar a lei ao caso, mas compor interesses, acomodando as intenções das partes. Daí a importância da confidencialidade nesse momento.

Uma boa medida do CPC é o fato de o réu apenas apresentar contestação após a audiência de conciliação ou do pedido de dispensa dessa. O réu não deve, conforme o Código, apresentar sua defesa antes da audiência de conciliação, o que facilita o diálogo entre as partes e aumenta a possibilidade de uma composição consensual do litígio. Na contestação, o réu deduz toda a sua matéria de defesa, apresentando sua percepção dos fatos e argumentos jurídicos. A apresentação da defesa antes da audiência certamente pode recrudescer o dissenso.

\subsection{A mediação e a Administração Pública. O Código de Processo Civil e a Lei 13.140/2015}

Em 2007, foi criada, no âmbito federal, a Câmara de Conciliação e Arbitragem da Administração Federal - CCAF, com a finalidade de prevenir e solucionar conflitos que envolvam a União ou entidade integrante da Administração Pública Federal, vindo, posteriormente, a abranger as controvérsias entre entes federais e entidades componentes da Administração Pública dos Estados, do Distrito Federal e de Municípios ${ }^{49}$.

Nos termos do art. 174 do CPC, a União, os Estados, o Distrito Federal e os Municípios devem criar câmaras de mediação e conciliação, com atribuições relacionadas à solução consensual de conflitos no âmbito administrativo. De acordo com o enunciado 94 do Fórum Nacional do Poder Público: "Nas câmaras administrativas, é dever do conciliador/mediador conduzir o procedimento de modo que as partes tenham acesso a informação sobre quaisquer questões que possam interferir na resolução do conflito, bem como registrar as providências adotadas a esse respeito".

Tais câmaras devem contribuir para solucionar conflitos envolvendo órgãos e entidades da Administração Pública, aí incluídos conflitos internos dentro da própria Administração. De igual modo, as câmaras de conciliação e mediação podem avaliar a admissibilidade dos pedidos de resolução de conflitos, por meio de conciliação, no âmbito da própria Administração Pública.

Também é possível que as referidas câmaras promovam a celebração de termo de ajustamento de conduta. Os termos de ajustamento de conduta, que têm sido celebrados no âmbito dos direitos difusos e coletivos, podem ser um bom instrumento de negociação em qualquer situação conflituosa, conduzida pelas câmaras de conciliação e mediação da Administração Pública.

A criação dessas câmaras, com tais finalidades, está igualmente prevista no art. 32 da Lei 13.140, de 2015, que trata da mediação entre particulares e entre particulares e, igualmente, sobre a autocomposição no âmbito do Poder Público. O princípio da eficiência exige que se criem câmaras de mediação, pois garantem maior economia, menos dispêndio e adequação na solução de disputas ${ }^{50}$.

49 Sobre a estrutura, composição e funcionamento da CCAF, consultar, com proveito, FACCI, Lucio Picanço. Meios adequados de resolução de conflitos administrativos: a experiência da Câmara de Conciliação e Arbitragem da Administração Federal. Rio de Janeiro: Lumen Juris, 2019, p. 161-200.

50 Nesse sentido, o enunciado 123 do Fórum Nacional do Poder Público: "A efetividade dos ideais de eficiência e economicidade na solução consensual de conflitos na Administração Pública exige a criação das câmaras previstas no art. 32 da Lei n. 13.140/15." 
Criada a câmara pelo ente público, seu regulamento deve indicar quais casos podem ser submetidos à mediação. A submissão do conflito à câmara é facultativa e somente será cabível nos casos previstos no seu regulamento. O ente público, todavia, deve justificar os motivos pelos quais recusa o convite para participar do procedimento de mediação ou de conciliação. ${ }^{51}$

A Administração Pública pode utilizar o procedimento previsto para a mediação com particulares, até que seja criada sua câmara de mediação (Lei 13.140/2015, art. 33). É possível, ainda, a instauração, de ofício ou por provocação, de procedimento de mediação coletiva de conflitos concernentes à prestação de serviços públicos (Lei 13.140/2015, art. 33, parágrafo único).

Enquanto não criadas as câmaras de prevenção e resolução administrativa de conflitos, as disputas podem ser resolvidas mediante procedimento de mediação, com marcação de reunião inicial, quando, então, será considerada instaurada a mediação. Na verdade, o art. 33 da Lei 13.140, de 2015, prevê a adoção do procedimento da mediação. Não há, rigorosamente, no que diz respeito às pessoas jurídicas de direito público, uma regulação a respeito da mediação.

Há a previsão de um procedimento para prevenção ou solução administrativa de conflitos, a ser conduzido pelos órgãos da Advocacia Pública, que se destina a dar solução extrajudicial à disputa. A Administração Pública vai examinar a pretensão do particular para, então, verificar se há procedência, então, acolher ou propor uma solução (Lei 13.140, de 2015, art. 32, II). No caso de litígios entre órgãos da Administração Pública, o órgão da Advocacia Pública vai examiná-los e resolvê-los; haverá, nessa hipótese, um julgamento administrativo (Lei 13.140, de 2015, art. 32, I).

A instauração de procedimento administrativo para resolução consensual do conflito no âmbito da Administração Pública - assim considerada quando o órgão ou entidade pública emitir juízo de admissibilidade - suspende a prescrição (Lei 13.140/2015, art. 34), independentemente de seu juízo positivo de admissibilidade.$^{52} \mathrm{O}$ que importa é o juízo de admissibilidade. Seja ele negativo, seja positivo, uma vez emitido, haverá suspensão da prescrição da pretensão a ser exercida contra a Fazenda Pública. A suspensão da prescrição retroage à data da formalização do pedido de resolução consensual do conflito (Lei 13.140/2015, art. 34, § 1 ${ }^{\circ}$ ).O advogado público pode atuar como mediador ou conciliador na câmara criada pelo ente público. ${ }^{53}$ Nos termos do art. $6^{\circ}$ da Lei 13.140, de 2015, "o mediador fica impedido, pelo prazo de um ano, contado do término da última audiência em que atuou, de assessorar, representar ou patrocinar qualquer das partes". Sobre a aplicação de tal dispositivo ao advogado público que atue como mediador ou conciliador, o enunciado 1 do Fórum Nacional do Poder Público assim está redigido: "Após atuar como mediador ou conciliador no âmbito da Administração Pública, o advogado público não fica impedido de assessorar, representar ou patrocinar o respectivo ente público, senão em relação ao outro participante da mediação e ao seu objeto, cumulativamente".

A autocomposição com o Poder Público pode ser feita por adesão, nos termos dos arts. 35 a 40 da referida Lei 13.140, de 2015. A formalização de resolução administrativa destinada à transação por adesão não implica interrupção ou suspensão da prescrição. De igual modo, não implica renúncia tácita à prescrição. Tudo isso está disposto no $§ 6^{0}$ do art. 35 da Lei 13.140, de 2015.

O acordo celebrado entre o Poder Público e o particular constitui título executivo extrajudicial, podendo fundamentar a propositura de uma ação de execução (Lei 13.140/2015, art. 32, § $3^{\circ}$ ).

O processo de mediação, mesmo quando envolva a Fazenda Pública, deve ser confidencial. A confidencialidade, como já demonstrado, é norma inerente à mediação e à conciliação. Segundo registrado no enunciado 36 do Fórum Nacional do Poder Público: "Durante o processo de mediação do particular com a Administração Pública, deve ser observado o princípio da confidencialidade previsto no artigo 30 da Lei 13.140/2015, ressalvando-se somente a divulgação da motivação da Administração

$51 \quad$ Nesse sentido, o enunciado 95 do Fórum Nacional do Poder Público: "Em atenção ao princípio da eficiência administrativa, ao recusar o convite para participar de processo conciliatório, o ente público deverá declinar os motivos pelos quais o faz".

52 Nesse sentido, o enunciado 37 do Fórum Nacional do Poder Público: "A suspensão da prescrição prevista no art. 34 da Lei 19.140/2015 ocorre independentemente do juízo positivo de admissibilidade”.

53 Também pode o advogado público atuar como mediador em mediação privada. Nesse sentido, o enunciado 38 do Fórum Nacional do Poder Público: "É compatível a atuação do advogado público como mediador na mediação privada". 
Pública e do resultado alcançado”. Tal enunciado teve sua redação posteriormente alterada, passando a ser assim redigido: "O conteúdo da sessão de mediação e de conciliação no âmbito da Administração Pública deve observar o princípio da confidencialidade, previsto nos artigos 30 da Lei 13.140/2015 e 166 do Código de Processo Civil, sem prejuízo da publicidade do resultado alcançado e sua respectiva motivação".

Há uma preocupação em compatibilizar a exigência de confidencialidade com o princípio da publicidade, inerente à atividade administrativa (CF, art. 37) e aplicável ao processo judicial. Por isso mesmo, não falta quem defenda a aplicação do $\$ 3^{\circ}$ do art. $1^{\circ}$ da Lei 9.307, de 1996, à mediação ou conciliação com o Poder Público, afirmando que não deve haver confidencialidade, a não ser nos casos em que a Lei 12.527, de 2011 (Lei do Acesso à Informação), estabeleça o dever de sigilo. ${ }^{54}$ Daí o teor do enunciado 6 do Fórum Nacional do Poder Público: "A confidencialidade na mediação com a Administração Pública observará os limites da lei de acesso à informação".

É um exagero essa afirmação.

Aliás, o referido enunciado 6 conflita com o também mencionado enunciado 36, ambos do Fórum Nacional do Poder Público. Exatamente por isso, o referido enunciado 6 do Fórum Nacional do Poder Público veio a ser expressamente cancelado.

O que é confidencial não é o processo no qual se realiza(m) a(s) sessão(ões) de mediação ou de conciliação. É preciso que se divulguem sua existência e os atos nele praticados. O conteúdo das sessões de mediação ou de conciliação que é sigiloso. E deve ser mesmo; para que viabilize a autocomposição, as partes precisam ter a garantia de que tudo o que disserem não poderá servir para a defesa da parte contrária. O princípio da publicidade não tem a amplitude que fundamenta a destacada preocupação. Fosse assim, todas as reuniões realizadas por autoridades públicas deveriam ser públicas, devendo toda conversa, negociação, diálogo ser divulgado e publicizado. O conteúdo das sessões de mediação e conciliação é sigiloso, mas o resultado e a motivação da Administração Pública são públicos e devem ser divulgados.

O processo judicial é público. Todos os atos são públicos. Mas as conversas, os debates, a negociação travada na sessão de mediação são confidenciais. Não obtida a autocomposição, segue o procedimento, todo público, mas as conversas não podem ser divulgadas, sob pena de inviabilizar qualquer negociação. Obtida a autocomposição, aí serão divulgados o resultado e a motivação do Poder Público. O que importa é o resultado: houve ou não autocomposição. Se não houve, é irrelevante saber o que se conversou. Se houve, devem ser divulgados o resultado e a motivação, como, aliás, está no enunciado 36 do Fórum Nacional do Poder Público.

A sessão de mediação ou de conciliação é confidencial, tal como estabelece o art. 30 da Lei 13.140, de 2015. Se as conversas ou informações forem registradas de algum modo e apresentadas em processo judicial ou arbitral, não devem ser admitidas (Lei 13.140/2015, art. 30, § $2^{\circ}$ ). É ilícita a prova que atente contra a confidencialidade. Não estão abrigadas pela confidencialidade as informações relativas à ocorrência de crime de ação pública; a confidencialidade não afasta o dever de prestação de informações às autoridades fazendária

Enfim, a confidencialidade é medida que se impõe durante as sessões de mediação e conciliação de que participa a Fazenda Pública.

\section{Conclusões}

O sistema de justiça multiportas é estruturado para que se concebam métodos adequados e integrados de solução de disputas: para cada tipo de disputa, há um meio próprio de solução. É preciso que se adote o meio adequado, a fim de que se possa ter efetividade na solução, com eficiência nas medidas empregadas.

54 PEIXOTO, Ravi. Os "princípios” da mediação e da conciliação: uma análise da Res. 125/2010 do CNJ, do CPC/2015 e da Lei 13.140/2015. In: ZANETI JR., Hermes; CABRAL, Trícia Navarro Xavier (coords.). Justiça multiportas: mediação, conciliação, arbitragem e outros meios de solução adequada de conflitos. Salvador: JusPodivm, 2016. n. 2.4.4, p. 100-101. 
Além da mediação, da conciliação, da arbitragem e de outros meios adequados e integrados, cabe às partes e aos seus advogados desenhar outro meio que se ajuste melhor à controvérsia instaurada.

A essa altura, cabe lembrar o exemplo do sujeito que tinha dezessete camelos, deixando, em seu testamento, a metade para um de seus filhos, um terço para outro e um nono para o terceiro. Falecido o autor da herança, o testamenteiro não conseguia executar o testamento, pois não sabia como fazer a divisão. Assim, consultou uma sábia da região, que disse não saber também como resolver, mas sugeriu que ele levasse seu camelo velho, que ela já não usava mais, e o adicionasse na soma para viabilizar a divisão. Assim, passou a haver dezoito camelos. A metade deles, ou seja, nove ficaram com o primeiro filho. Um terço deles, ou seja, seis ficaram para o segundo filho. E, finamente, um novo deles, ou seja, dois ficaram para o terceiro filho. Então, somando-se nove, seis e dois, tinham-se os dezessete camelos adequadamente divididos entre os herdeiros. Sobrou o camelo da sábia senhora, que lhe fora oportunamente devolvido ${ }^{55}$.

A solução, no ilustrado exemplo, veio com a adição do décimo oitavo camelo. Muitas vezes, para que se dê solução a um caso, é preciso encontrar o décimo oitavo camelo. O sistema de justiça multiportas recomenda a adoção dos meios já conhecidos de solução de disputas, mas também sugere criatividade na construção ou no desenho do meio adequado, específico, que se ajuste às peculiaridades do caso, como adicionar o décimo oitavo camelo no exemplo acima ilustrado.

\section{Referências}

AMARAL, Paulo Osternack. Arbitragem e Administração Pública. Belo Horizonte: Fórum, 2012.

BARREIROS, Lorena Miranda Santos. Convenções processuais e Poder Público. Salvador: JusPodivm, 2016.

BONÍCIO, Marcelo José Magalhães. Breve análise sobre a arbitragem em conflitos que envolvem o Estado. Revista da Procuradoria Geral do Estado de São Paulo. São Paulo, v. 75, p. 13-20, 2012.

CAHALI, Francisco José. Curso de arbitragem. São Paulo: RT, 2011.

CÂMARA, Alexandre Freitas. Mediação e conciliação na Res. 125 do CNJ e no projeto de Código de Processo Civil. O processo em perspectiva: jornadas brasileiras de direito processual. São Paulo: RT, 2013.

CAPPELLETTI, Mauro; GARTH, Bryant. Acesso à justiça. Porto Alegre: Sérgio Antonio Fabris, 1988.

CARMONA, Carlos Alberto. Arbitragem e processo: um comentário à Lei no 9.307/96. 2ª . ed. São Paulo: Atlas, 2004.

CHASE, Oscar G. Derecho, cultura y ritual: sistemas de resolución de controversias en un contexto intercultural. Madrid: Marcial Pons, 2011.

COELHO, Renata Moritz Serpa. Atualidades sobre a mediação de conflitos no Brasil a partir de 2015. Revista de Processo. São Paulo: RT, v. 272, out.-2017.

COSTA, Nilton César Antunes da. Poderes do árbitro. São Paulo: RT, 2002.

CUNHA, Leonardo Carneiro da; CABRAL, Antonio do Passo. Negociação direta ou resolução colaborativa de disputas (collaborative law): "mediação sem mediador". Revista de Processo, São Paulo: RT, v. 259, p. 471-489, set. 2016.

DIDIER JR., Fredie; CABRAL, Antonio do Passo; CUNHA, Leonardo Carneiro da. Por uma nova teoria dos procedimentos especiais: dos procedimentos às técnicas. Salvador: JusPodivm, 2018.

DINAMARCO, Cândido Rangel. A arbitragem na teoria geral do processo. São Paulo: Malheiros, 2013.

ENGEL, Martin. Collaborative law: mediation ohne mediator. Tübingen: Mohr Siebeck, 2010.

FACCI, Lucio Picanço. Meios adequados de resolução de conflitos administrativos: a experiência da Câmara de Conciliação e Arbitragem da Administração Federal. Rio de Janeiro: Lumen Juris, 2019.

55 Exemplo extraído, com adaptações nos números, de TAHAN, Malba. O homem que calculava. 92a ed. Rio de Janeiro: Record, 2018, p. 21-23. 
FALECK, Diego. Manual de design de sistema de disputas: criação de estratégias e processos eficazes para tratar conflitos. Rio de Janeiro: Lumen Juris, 2018.

FIGUEIRA JÚNIOR, Joel Dias. Arbitragem, jurisdição e execução: análise crítica da Lei 9.307/96, de 23.09.1996. São Paulo: RT, 1999.

GOUVEIA, Mariana França. Curso de resolução alternativa de litígios. Coimbra: Almedina, 2011.

GUERRERO, Luís Fernando. Tutela de urgência e arbitragem. Revista Brasileira de Arbitragem,. Porto Alegre: Síntese, v. 6, n. 24, Curitiba: Comitê Brasileira de Arbitragem, 2009.

LESSA NETO, João Luiz. O novo CPC adotou o modelo multiportas!!! E agora?!. Revista de Processo. São Paulo: RT, v. 244, p. 427-441, jun. 2015.

Medidas cautelares, arbitragem e a cooperação com o poder judiciário. Execução e cautelar: estudos em homenagem a José de Moura Rocha. In: ADONIAS, Antonio Adonias; DIDIER JR., Fredie Didier Jr.; CUNHA, Leonardo Carneiro da Cunha (coords.). Execução e cautelar: estudos em homenagem a José de Moura Rocha. Salvador: JusPodivm, 2012.

LIMA, Raimundo Márcio Ribeiro. Administração Pública dialógica. Curitiba: Juruá, 2013.

MELLO, Marcos Bernardes de. Teoria do fato jurídico: plano da eficácia - $1^{\underline{a}}$ parte. São Paulo: Saraiva, 2003.

NOBRE JÚNIOR, Edilson Pereira. As normas de direito público na Lei de Introdução ao Direito Brasileiro: paradigmas para interpretação e aplicação do Direito Administrativo. São Paulo: Contracorrente, 2019.

NUNES, Dierle; TEIXEIRA, Ludmila. Acesso à justiça democrático. Brasília: Gazeta Jurídica, 2013. OLIVEIRA, Ana Perestrelo. Arbitragem de litígios com entes públicos. 2. ed. Coimbra: Almedina, 2015. PEIXOTO, Ravi. Os "princípios” da mediação e da conciliação: uma análise da Res. 125/2010 do CNJ, do CPC/2015 e da Lei 13.140/2015. In: ZANETI JR., Hermes; CABRAL, Trícia Navarro Xavier (coords.). Justiça multiportas: mediação, conciliação, arbitragem e outros meios de solução adequada de conflitos. Salvador: JusPodivm, 2016.

ROSA, José Carlos. Medidas cautelares e arbitragem. São Paulo: Opera Nostra, 2006.

SANDER, Frank. Varieties of dispute processing. In: LEVIN, A. Leo; WHEELER, Russell R. The pound conference: perspectives on justice in the future. Saint Paul: West Publishing Co., 1979.

SARAIVA, Leonardo. Arbitragem na Administração Pública. Rio de Janeiro: Lumen Juris, 2019.

SILVA, Almiro do Couto e. Os indivíduos e o Estado na realização de tarefas públicas. Conceitos fundamentais do direito no Estado Constitucional. São Paulo: Malheiros, 2015.

TAHAN, Malba. O homem que calculava. 92aㅡ ed. Rio de Janeiro: Record, 2018.

TARTUCE, Fernanda. Mediação nos conflitos civis. 2. ed. São Paulo: Método, 2015.

URY, William; BRETT, Jeanne; GOLDBERG, Stephen. Resolução de conflitos. Trad. Soares Franco. Lisboa: Actual Editora, 2009.

VASCONCELOS, Carlos Eduardo. Mediação de conflitos e práticas restaurativas. $4^{\mathrm{a}}$ ed. São Paulo: Método, 2015.

WATANABE, Kazuo. Política judiciária nacional de tratamento adequado dos conflitos de interesses: utilização dos meios alternativos de resolução de controvérsias. O processo em perspectiva: jornadas brasileiras de direito processual. São Paulo: RT, 2013. 